\title{
The Use of Fluorescent Probes to Assess Viability of the Plant Pathogenic Bacterium Clavibacter michiganensis subsp. michiganensis by Flow Cytometry
}

\author{
Luiz G. Chitarra ${ }^{1,2,3}$, Peter Breeuwer ${ }^{2}$, Tjakko Abee ${ }^{2} \&$ Ruud W. Bulk ${ }^{1}$ \\ ${ }^{1}$ Business Unit Plant Development and Reproduction, Plant Research International, P.O. Box 16, 6700 AA, Wageningen, \\ The Netherlands; ${ }^{2}$ Department of Agrotechnology and Food Sciences, Wageningen University, P.O. Box 8129, 6700 EV, \\ Wageningen, The Netherlands; ' ${ }^{E}$ mbrapa Algodão, Cx. Postal 174, CEP 58107-720, Campina Grande, PB, Brazil, \\ e-mail: chitarra@cnpa.embrapa.br
}

(Accepted for publication 04/10/2006)

Corresponding author: Luiz Gonzaga Chitarra

CHITARRA, L.G., BREEUWER, P., ABEE, T. \& BULK, R.W. The use of fluorescent probes to assess viability of the plant pathogenic bacterium Clavibacter michiganensis subsp. michiganensis by flow cytometry. Fitopatologia Brasileira 31:349-356. 2006.

\begin{abstract}
Determination of the viability of bacteria by the conventional plating technique is a time-consuming process. Methods based on enzyme activity or membrane integrity are much faster and may be good alternatives. Assessment of the viability of suspensions of the plant pathogenic bacterium Clavibacter michiganensis subsp. michiganensis $(\mathrm{Cmm})$ using the fluorescent probes Calcein acetoxy methyl ester (Calcein AM), carboxyfluorescein diacetate (cFDA), and propidium iodide (PI) in combination with flow cytometry was evaluated. Heat-treated and viable (non-treated) Cmm cells labeled with Calcein AM, cFDA, PI, or combinations of Calcein AM and cFDA with PI, could be distinguished based on their fluorescence intensity in flow cytometry analysis. Nontreated cells showed relatively high green fluorescence levels due to staining with either Calcein AM or cFDA, whereas damaged cells (heat-treated) showed high red fluorescence levels due to staining with PI. Flow cytometry also allowed a rapid quantification of viable Cmm cells labeled with Calcein AM or cFDA and heat-treated cells labeled with PI. Therefore, the application of flow cytometry in combination with fluorescent probes appears to be a promising technique for assessing viability of Cmm cells when cells are labeled with Calcein AM or the combination of Calcein AM with PI.
\end{abstract}

Additional Keywords: cFDA, Calcein AM, propidium iodide.

\section{RESUMO}

Uso de sondas fluorescentes na avaliação da viabilidade de Clavibacter michiganensis subsp. michiganensis por citometria de fluxo A determinação da viabilidade de bactérias através da técnica tradicional de plaqueamento em meios seletivos de cultura é considerada um processo longo e demorado. Os métodos baseados na atividade enzimática ou na integridade da membrana citoplasmática são mais rápidos e podem ser considerados como alternativas para acessar a viabilidade de bactérias fitopatogênicas. Este trabalho teve o objetivo de avaliar a viabilidade de suspensões de culturas puras da bactéria Clavibacter michiganensis subsp. michiganenesis (Cmm) usando as sondas fluorescentes "Calcein acetoxy methyl ester" (Calcein AM), "carboxyfluorescein diacetate" (cFDA), e "propidium iodide" (PI), em combinação com o citômetro de fluxo. Células de Cmm tratadas à temperatura de $80{ }^{\circ} \mathrm{C}$ por 30 min (não viáveis) e células não tratadas (viáveis), marcadas com Calcein AM, cFDA, PI, ou utilizando a combinação das sondas Calcein AM e cFDA com PI, puderam ser distinguidas baseado na intensidade de fluorescência através da análise do citômetro de fluxo. Células não tratadas mostraram nível elevado de intensidade de fluorescência no espectro verde, devido à coloração das células com Calcein AM ou cFDA, enquanto que as células danificadas (não viáveis) mostraram nível elevado de intensidade de fluorescência no espectro vermelho, devido à coloração com PI. O citômetro de fluxo permitiu também a quantificação rápida das células viáveis de Cmm marcadas com Calcein AM ou cFDA e das células tratadas marcadas com PI. Portanto, a aplicação do citômetro de fluxo, em combinação com sondas fluorescentes, parece ser uma técnica promissora para acessar a viabilidade de células de Cmm, quando estas são marcadas com Calcein AM ou utilizando a combinação de Calcein AM com PI.

Palavras-chave adicionais: cFDA, Calceina AM, propidium iodide.

\section{INTRODUCTION}

Bacterial canker of tomato, caused by the seedtransmitted plant pathogenic bacterium Clavibacter michiganensis subsp. michiganensis Smith (Davis et al., 1984), causes major economic losses in commercial tomato production worldwide. To prevent the introduction of bacterial canker, disease-free seeds should be used. Indexing seeds for the presence of $C$. michiganensis $(\mathrm{Cmm})$ is recommended to select for disease-free seeds. Information on the viability of the target bacterium is essential for decision-making by seed companies regarding processing and treatments of seed lots. In addition, information on viability is helpful to determine the effect of seed treatments. Therefore, accurate and rapid 
methods to assess the viability of plant pathogenic bacteria, such as $\mathrm{Cmm}$, are highly desirable.

Here we define viability as the capability of a cell to perform all the necessary functions for its survival under given conditions. Viable microorganisms require an intact cytoplasmic membrane, DNA transcription and RNA translation, enzyme activity, and growth (Breeuwer et al., 1996). The plate count method is commonly applied for detection and enumeration of viable bacteria and involves plating serial dilutions of an extract or washing in a selective medium. Subsequently, the isolated organisms may be identified by a range of biochemical and serological tests. However, the plate count method is time consuming (Plihon et al., 1995) and the results are sometimes difficult to interpret due to cell concentration effects, interference by other microorganisms, or presence of inhibitory components.

The development of fluorescent probes for cellular functions has led to new techniques for measuring the viability of microorganisms (Haugland, 1996). Various fluorescent probes have the ability to explore different properties of the cell, such as enzyme activity (Kaneshiro et al., 1993; Diaper \& Edwards, 1994a, 1994b; Endo et al., 1997; Bunthof et al., 1999; Bunthof et al., 2001; Ben-Amor et al., 2002; Luppens et al., 2003); cytoplasmic membrane permeability (Magariños et al., 1997; Porter et al., 1997; Williams et al., 1998; Gregori et al., 2001; Hewitt \& Nebe-Von-Caron, 2001), membrane potential (Mason et al., 1995; Langsrud \& Sundheim, 1996; Lopes-Amoros et al., 1997; Ludovico et al., 2001), respiratory activity (Kaprelyants \& Kell, 1993a, 1993b; Gunasekera et al., 2003; Yamaguchi et al., 2003; Nielsen et al., 2003), relative DNA content (Sgorbati et al., 1996; Bernander et al., 1998) and $\mathrm{pH}$ gradient (Breeuwer et al., 1996; Chitarra et al., 2000). Several of these parameters can be used as indicators of viability.

One of the enzyme activity probes that has been used as a cell viability indicator is fluorescein diacetate (FDA). FDA is a non-fluorescent polar ester compound that can permeate intact cell membranes. Once inside the cell it is cleaved (hydrolysed) by non-specific esterases to release fluorescein, a polar fluorescent compound which is retained inside the cells. Thus, the viability can be correlated with the ability of the cell to accumulate fluorescein due to esterase activity (Widholm, 1972). However, fluorescein is poorly retained by viable cells (Edwards et al., 1993), and the FDA method can be easily frustated due to leakage or active efflux of fluorescein to the extracellular environment. This first problem can be minimized by using probes which are more negatively charged at physiological $\mathrm{pH}$, resulting in less leakage of fluorescein from the cells. Such probes are for instance carboxyfluorescein diacetate (cFDA) and calcein acetoxy methyl ester (Calcein AM). To prevent active extrusion, the assay has to be performed with deenergized cells in buffer without energy source, or on a very short timescale.

Propidium iodide (PI) is a nucleic acid probe that has also been used successfully to assess viability of microorganisms (Sgorbati et al., 1996; Magariños et al., 1997). PI is not capable of crossing intact membranes of living microorganisms (Alvarado-Aleman et al., 1996), but it passes through damaged cell membranes. Once inside the cell, PI intercalates into RNA and DNA backbones independently of base pair ratio (Taylor \& Milthorpe, 1980) and A·T-rich regions (Crissman et al., 1979). It can also form complexes with double-stranded DNA and RNA (Hudson et al., 1969). PI-stained cells are assumed to be non-viable.

The potential of such viability measurements is increased when applied in combination with flow cytometry (FCM), a technique highly suited to the rapid analyses of individual, fluorescent cells.

The aim of the present paper was to test the enzyme activity probes cFDA and Calcein AM, and the nucleic acid probe PI in combination with FCM, to determine the viability of $\mathrm{Cmm}$ cells. The results are compared with those of the conventional plate count technique.

\section{MATERIALS AND METHODS}

\section{Growth conditions}

Clavibacter michiganensis subsp. michiganensis (Cmm) NCPPB 1064 was grown on $1 \%$ Glucose-NutrientAgar (GNA; Oxoid) medium for 24 hours at $25{ }^{\circ} \mathrm{C}$. The cells were harvested and re-suspended in $0.2 \mathrm{M}$ sodium phosphate buffer $\left(\mathrm{SP}_{\mathrm{i}}\right) \mathrm{pH}$ 7.4. The Optical Density (O.D.) was measured with a spectrophotometer at $620 \mathrm{~nm}$ and adjusted by diluting with $\mathrm{SP}_{\mathrm{i}}$ to approximately 0.35 , in order to obtain concentrations of $10^{6}$ to $10^{7}$ colony-forming units per $\mathrm{ml}\left(\mathrm{CFU} \mathrm{mL} \mathrm{m}^{-1}\right)$.

\section{Temperature treatment}

To obtain non-viable bacterial cells, the bacterial suspensions were heat-treated (Test Tube Heater SHT 2D) at $80{ }^{\circ} \mathrm{C}$ for 30 minutes.

Non-treated and heat-treated bacterial cells were mixed in different ratios, i.e. 100/0, 80/20, 50/50, 20/80, and $0 / 100 \%$ respectively, to create populations varying in the percentage of viable cells.

\section{Labeling of cells with fluorescent probes}

Cmm cells in $\mathrm{SP}_{\mathrm{i}} \mathrm{pH} 7.4$ were incubated for 1 hour at $28{ }^{\circ} \mathrm{C}$ in the presence of cFDA $(10 \mu \mathrm{M})$, Calcein AM $(10$ $\mu \mathrm{M})$, or either probe in combination with PI $(10 \mu \mathrm{M})$ for double labeling. Samples to be stained with PI alone were incubated for 20 minutes at room temperature. Subsequently, the cells were spun down at $11000 \mathrm{~g}$, washed, re-suspended in $\mathrm{SP}_{\mathrm{i}} \mathrm{pH}$ 7.4, and placed on ice until required.

\section{Flow cytometric analysis}

Analysis of individual cells was performed with a FACSCalibur flow cytometer (Becton-Dickinson Benelux N.V., Erembodegem, Belgium), equipped with an aircooled argon ion laser (excitation wavelength $488 \mathrm{~nm}$ ), which was operated at $15 \mathrm{~mW}$. The instrument was set up 
to collect 6 parameters: forward and side scatter, fluorescent light at emission wavelengths of 530/30 nm (FL-1; green fluorescence), 585/42 (FL-2; orange fluorescence), and > $670 \mathrm{~nm}$ (FL-3; red fluorescence), and time. The low angle light scatter (forward scatter) was used as an indicator of cell size and the wide angle light scatter $\left(90^{\circ}\right.$ or side scatter $)$ was used as an indicator of cell granularity. The results are represented in 2 parameter dot plots in which the $\mathrm{X}$-axis and $\mathrm{Y}$-axis are divided into 1024 channels, relative to the intensity of the incoming signal. A logarithmic amplification of the incoming signal was used to measure a wider range of signals ( 4 decade log scale). The sample analysis time was approximately 2 minutes and the number of labeled bacterial cells was quantified based on the flow rate, which was determined to be $4.8 \mu 1 \mathrm{~min}^{-1}$. The cells were separated from the background by their side scatter characteristics. Non-treated (viable) unstained cells were used as negative controls for Calcein AM and cFDA, and heat-treated (nonviable) unstained cells for PI.

To verify that green and red fluorescent cells represent live (non-treated) and dead (heat-treated) bacterial cells, respectively, cells from defined populations were sorted and plated.

\section{Sorting of viable and non-viable cells}

$\mathrm{Cmm}$ cells labeled with Calcein AM, cFDA or PI were sorted based on the green and red fluorescence of the cells at wavelengths of 530 and $>670 \mathrm{~nm}$ respectively. Calcein $\mathrm{AM}$ and cFDA positive cells give high green fluorescence signal (viable cells), and PI positive cells give a high red fluorescence signal (non-viable cells). Cells from these two distinct fluorescence regions were sorted, counted by the flow cytometer, and $50 \mu \mathrm{L}$ drops containing sorted viable or non-viable cells were plated on GNA medium. After incubation of plates for 96 hours at $25^{\circ} \mathrm{C}$, the number of colonies was counted and the total number of CFU mL $\mathrm{mL}^{-1}$ was calculated. Sorted cells were also counted in a Neubauer counting chamber.

\section{Total cell counts}

Four replicates of each sample were counted in a Neubauer counting chamber with a fluorescence microscope (Zeiss, Axiophoto, West Germany) at a magnification of $10 \times 40$. The total count determination was carried out by counting the non-treated cells stained with Calcein AM or cFDA (green fluorescence), and heat-treated cells stained with PI (red fluorescence). Non-labeled cells were counted as well (control).

\section{Plate count technique}

Plate counts were determined as described by Miles \& Misra (1933). Serial ten-fold dilutions were made from each bacterial suspension in $\mathrm{SP}_{\mathrm{i}} \mathrm{pH} 7.4$, and $20 \mu \mathrm{L}$ drops of each dilution were plated in triplicate on sectored GNA plates. After incubation of plates for $72 \mathrm{~h}$ at $25^{\circ} \mathrm{C}$, the number of colonies was counted for those dilutions producing between
3 and 30 colonies per $20 \mu \mathrm{L}$ drop, and the total number of $\mathrm{CFU} \mathrm{mL} \mathrm{m}^{-1}$ was calculated for each sample.

\section{RESULTS}

For the FCM-based viability assay, $\mathrm{Cmm}$ cells were labeled with Calcein AM, cFDA, PI, or combinations of Calcein AM and cFDA with PI, and analyzed. The number of green and/or red fluorescent particles, labeled with Calcein AM, cFDA or PI was quantified. Green particles represented cells with intact membranes and esterease activity, whereas red particles represented cells with a damaged membrane (Fig. 1). The FCM analyses showed that individual cells

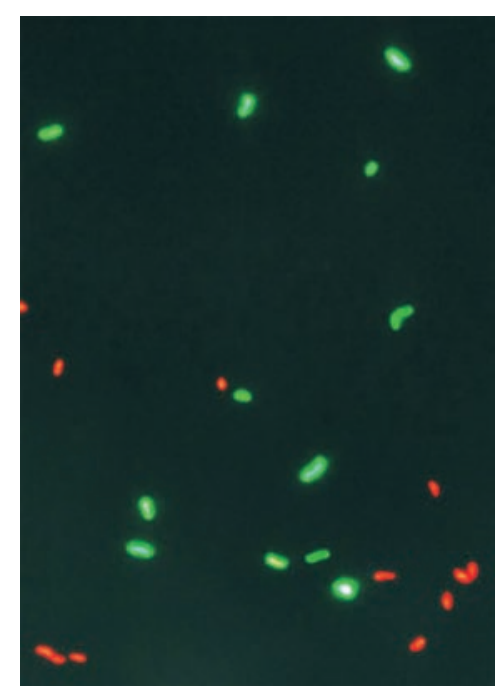

FIG. 1 - Fluorescence microscopy of Cmm cells labeled with Calcein AM (green fluorescence) and PI (red fluorescence).

labeled with Calcein AM or cFDA, and cells labeled with PI could be separated into two highly distinct regions based on the wavelength and intensity of the fluorescence, as shown for instance in a $\mathrm{Cmm}$ population containing $50 \%$ heattreated cells (Fig. 2). Non-treated Calcein AM-stained cells showed relatively high levels of green fluorescence (R2), whereas damaged cells (heat-treated) showed high levels of red fluorescence when stained with PI (R3).

The quantitative results of the FCM analyses were compared with total counts and plate counts for populations containing 100, 80, 50, 20 and $0 \%$ viable $\mathrm{Cmm}$ cells. The total counts were all in the same range, i.e. 2.0 to $2.8 \times 10^{7}$ cells $\mathrm{mL}^{-1}$, which proved that the number of $\mathrm{Cmm}$ cells was similar in all samples, irrespective of the label used or treatment given. The total counts and FCM counts of nonheat treated cells labeled with Calcein AM (Fig. 3) or cFDA (Fig. 4) were almost the same, but the number of CFU mL detected by plate counts was much lower. A linear relation $\left(r^{2} \geq 0.95\right)$ was found between the percentage of non-treated cells present in the samples and the FCM counts for $\mathrm{Cmm}$ 


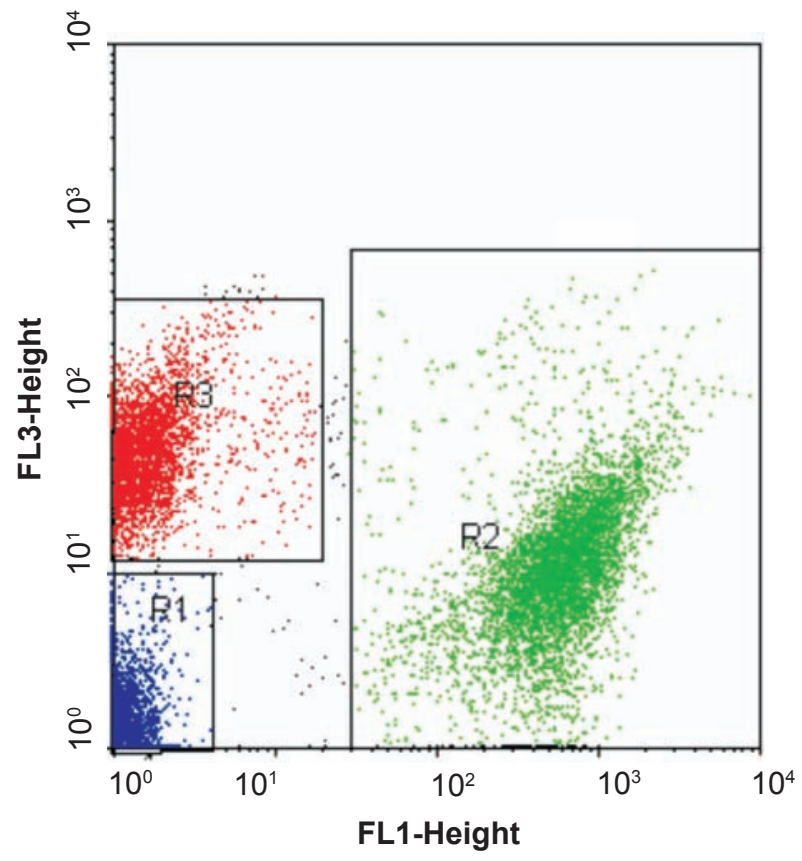

FIG. 2 - Green fluorescence intensity (FL1) and red fluorescence intensity (FL3) of a Cmm population containing 50\% heat-treated cells labeled with Calcein $\mathrm{AM}$ (R2) and PI (R3). R1 = background.
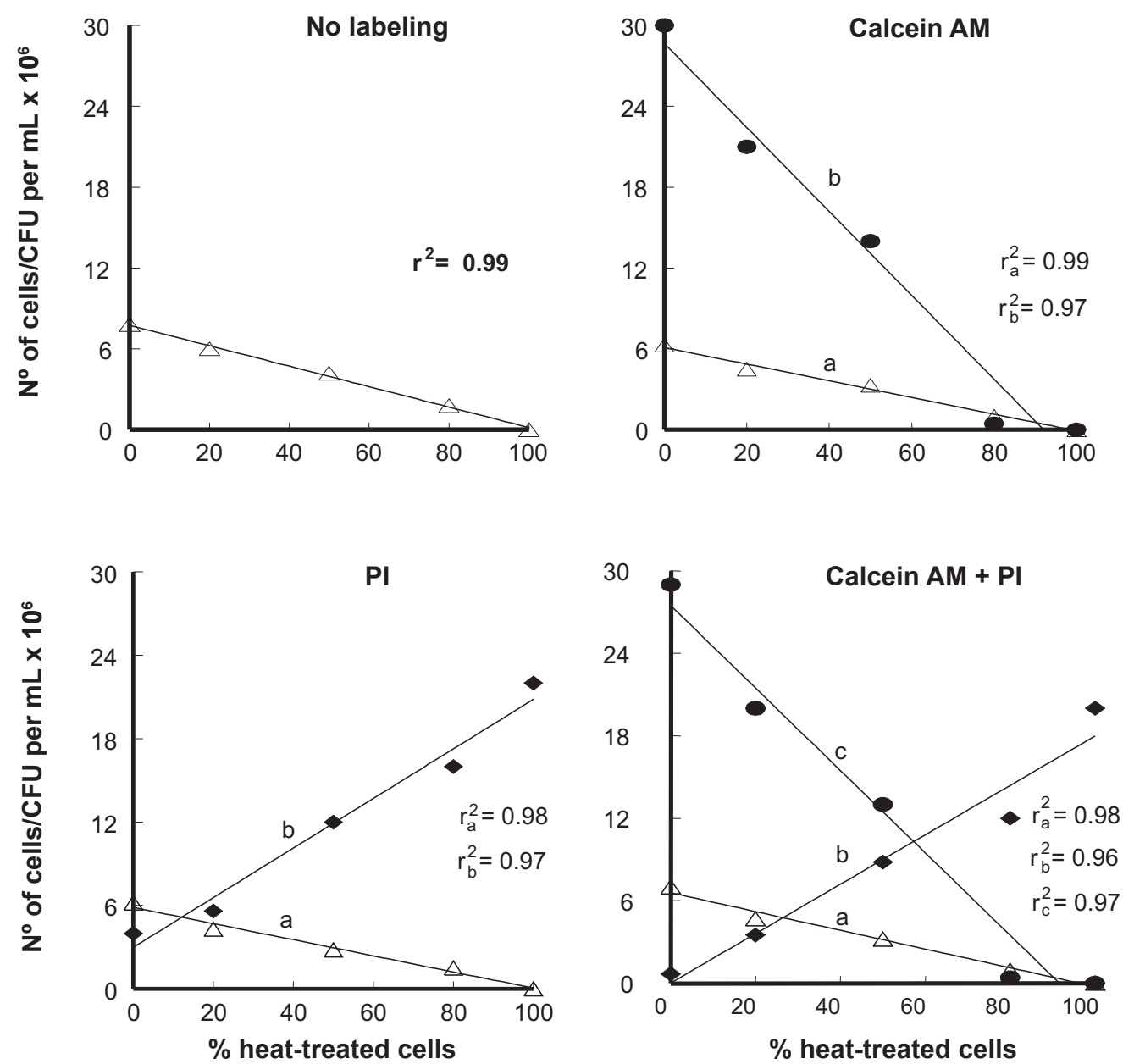

FIG. 3 - Comparison between plate counts (D) and flow counts for different ratios of non-treated and heat-treated Cmm cells labeled with Calcein AM $(\bullet)$ or PI $(\bullet)$. 

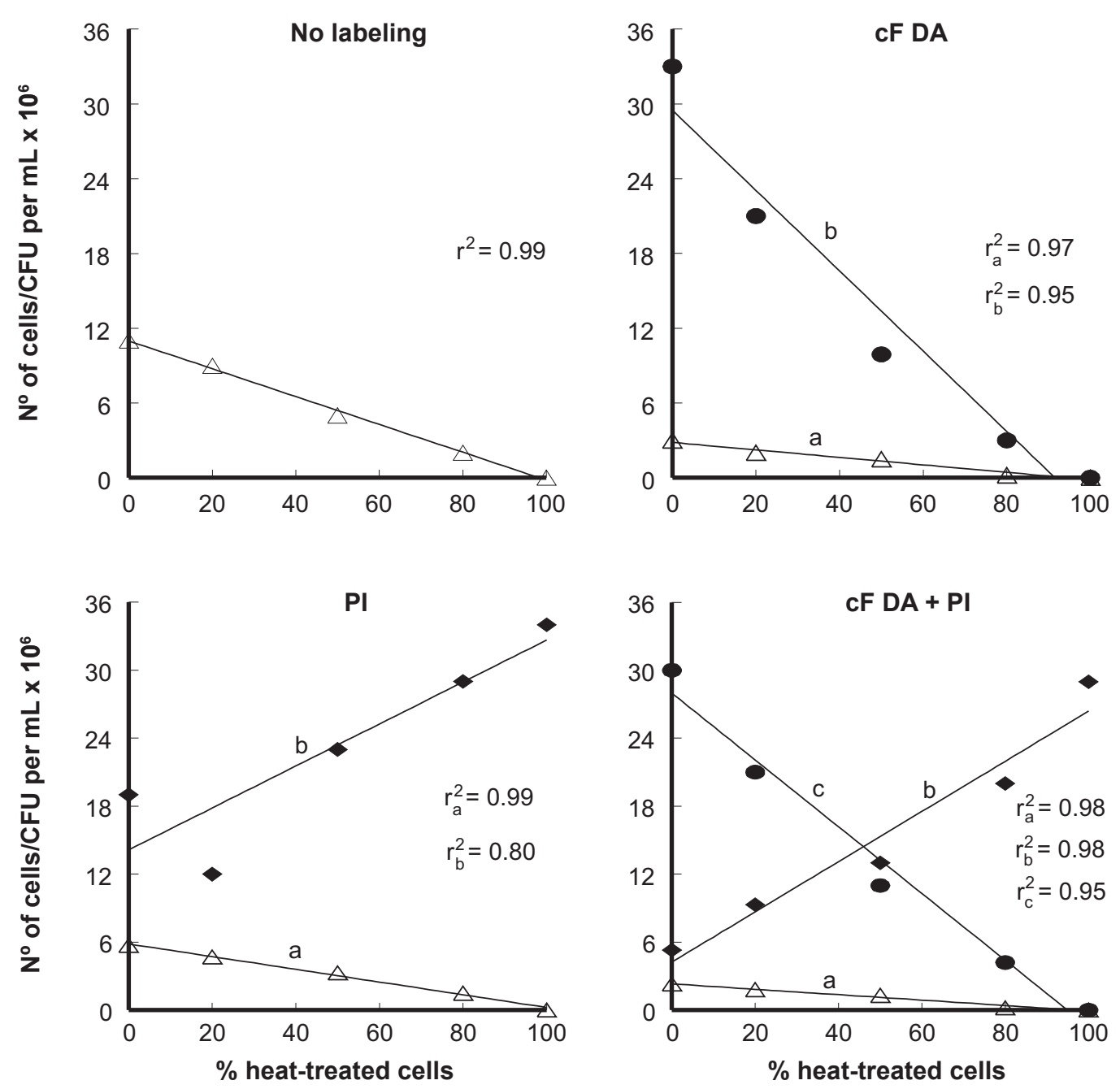

FIG. 4 - Comparison between plate counts (D) and flow counts for different ratios of non-treated and heat-treated Cmm cells labeled with $\mathrm{cFDA}(\bullet)$ or PI $(\bullet)$.

cells labeled with Calcein AM or cFDA.

A linear relation $\left(r^{2} \geq 0.80\right)$ was also found between the percentage of heat-treated cells in the samples and the FCM counts for Cmm cells labeled with PI. However, the labeling with cFDA and PI appeared to affect outgrowth of the $\mathrm{Cmm}$ cells after plating, since the number of $\mathrm{CFU} \mathrm{mL}^{-}$ ${ }^{1}$ showed a decrease of $72 \%$ and $52 \%$ compared to nonlabeled cells, respectively. The plate counts showed that the recovery of $\mathrm{Cmm}$ cells in the presence of Calcein $\mathrm{AM}$ was higher than in the presence of cFDA. Indeed, the sorting of cells labeled with cFDA showed that only $0.6 \%$ to $5 \%$ of these cells could form colonies after plating (Table 1). For Cmm cells labeled with Calcein AM , 42 to $65 \%$ of the sorted cells were able to form colonies. It should be taken into account that the concentration of plated cells was low, possibly affecting the outgrowth of the cells. As expected, sorted cells labeled with PI could not be recovered at all after plating on GNA.

Overall, the number of non-treated $\mathrm{Cmm}$ cells labeled with Calcein AM, cFDA, PI, or a combination of these probes, quantified by FCM analyses, was comparable to the number of total counts and both were higher than the number of CFU mL $\mathrm{mL}^{-1}$ detected by plate counting.

\section{DISCUSSION}

The assessment of the viability of the plant pathogenic bacterium Cmm, applying the fluorescent probes Calcein $\mathrm{AM}$, cFDA and PI in combination with flow cytometry, was evaluated for $\mathrm{Cmm}$ populations differing in the ratio of viable/non-viable cells. The use of flow cytometry to distinguish between viable and non-viable bacteria after labeling with cFDA, Calcein AM or PI has been reported before for microorganisms in food, compost extracts, seawater (Bunthof et al., 2001, Diaper \& Edwards, 1994a, 1994b; Magariños et al., 1997) and for bacterium of the human gastrointestinal tract (Ben-Amor et al., 2002). The viability of $\mathrm{Cmm}$ cells in suspension has also been 
TABLE 1 - Colony formation of sorted Cmm cells labeled with Calcein AM, cFDA, PI or combinations of Calcein AM and cFDA with PI, after plating on GNA medium

\begin{tabular}{|c|c|c|c|}
\hline Label & $\begin{array}{l}\text { Cmm population } \\
\% \text { heat treated cells }\end{array}$ & $\begin{array}{c}\text { Concentration of sorted cells } \\
\left(\text { cells } \mathrm{mL}^{-1}\right)\end{array}$ & $\begin{array}{l}\text { Plate counts of sorted cells } \\
\left(\mathrm{CFU} \mathrm{mL} \mathrm{mL}^{-1}\right)\end{array}$ \\
\hline Calcein AM & 0 & $2.4 \times 10^{3}$ & $9.8 \times 10^{2}(42 \%)$ \\
\hline PI & 100 & $4.8 \times 10^{2}$ & 0 \\
\hline Calcein AM + PI & 50 & $\begin{array}{c}9.7 \times 10^{2}(\text { Calcein AM stained }) \\
4.2 \times 10^{2}(\text { PI stained })\end{array}$ & $\begin{array}{c}6.3 \times 10^{2}(65 \%) \\
0\end{array}$ \\
\hline $\mathrm{cFDA}$ & 0 & $3.9 \times 10^{3}$ & $2.0 \times 10^{2}(5 \%)$ \\
\hline PI & 100 & $2.6 \times 10^{3}$ & 0 \\
\hline $\mathrm{cFDA}+\mathrm{PI}$ & 50 & $\begin{array}{c}2.5 \times 10^{3}(\mathrm{cFDA} \text { stained }) \\
3.5 \times 10^{3}(\mathrm{PI} \text { stained })\end{array}$ & $\begin{array}{c}1.6 \times 10(0.6 \%) \\
0\end{array}$ \\
\hline
\end{tabular}

determined by measuring the intracellular $\mathrm{pH}$ as a viability indicator, using the $\mathrm{pH}$ dependent fluorescent probe 5 (and 6)-carboxyfluorescein succinimidyl ester (cFSE) and FCM (Chitarra et al., 2000). However, compared to the method applied in this study, the intracellular $\mathrm{pH}$ analysis has to be performed at two $\mathrm{pH}$ values, the preparation of the samples takes a longer time, a calibration curve has to be made each time, and the results are more difficult to interpret.

In this study, we observed that non-treated (viable) and heat-treated (non-viable) $\mathrm{Cmm}$ cells could be distinguished based on the fluorescence intensity of the cells after labeling with Calcein AM or cFDA (green fluorescence), and PI (red fluorescence). A good correlation was found between the percentage of viable $\mathrm{Cmm}$ cells and the FCM counts when the cells were Calcein AM-stained. These results differ from the results reported by Kaneshiro et al. (1993) and Diaper \& Edwards (1994b). Their research showed the inability of Calcein AM to stain many yeast and bacterial cells, probably due to poor accessibility of the cells for this dye.

cFDA is a widely used fluorogenic ester that is applied to detect viable bacteria using fluorescence microscopy (Chrzanowski et al., 1984) and flow cytometry (Diaper \& Edwards, 1994a, 1994b; Bunthof et al., 2001; Ben-Amor et $a l ., 2002)$. Since this dye preferentially stains gram-positive bacteria, it was expected to be a good viability indicator for $\mathrm{Cmm}$. However, comparing cFDA and Calcein AM, the latter showed more reliable results, and appears to be a good indicator for viability of $\mathrm{Cmm}$ cells when applied in combination with FCM.

PI is a dye that is supposed not to cross intact cell membranes (Alvarado-Aleman et al., 1996), but it was able to stain 18 to $56 \%$ of non-treated Cmm cells when applied as a single stain. These results suggest that PI cannot be considered a good viability indicator for viable $\mathrm{Cmm}$ cells when it is applied alone. However, it was shown that it can be a good indicator for dead or damaged cells.

The number of labeled cells detected by FCM analyses was always higher than the number of $\mathrm{CFU} \mathrm{mL} \mathrm{m}^{-1}$ detected by the plate count method. This implies that a large proportion of the cells are enzymatically active, e.g. they are able to hydrolyse Calcein AM and cFDA, but only about 55 $\%$ and $24 \%$, respectively, of stained cells are able to form colonies. Nonetheless, both plate count and FCM results show a linear relationship with the percentage of viable $\mathrm{Cmm}$ cells in the population. FCM analysis of Calcein AM stained cells can therefore be used as a viability indicator as well, being superior to the conventional plate count method due to its short assay time.

Future work will focus on establishing an FCM method that specifically detects $\mathrm{Cmm}$ cells by means of labeled antibodies and measures the viability of those cells with a viability probe, such as Calcein AM, in the same assay. Such a method can then be used to determine the viability of $\mathrm{Cmm}$ cells in complex matrizes containing other microorganisms, such as plant or seed extracts.

\section{ACKNOWLEDGEMENT}

We thank the Fundação Coordenação de Aperfeiçoamento de Pessoal de Nível Superior - CAPES (Brazil) for providing financial support to L. G. Chitarra during this study.

\section{REFERENCES}

ALVARADO-ALEMAN, F.J., COLLAZO-PONCE, A. \& KUMATE-RODRIGUES, J. Assessment of viability of yeast by flow cytometry using light green as vital dye exclusion. Revista Latino-Americana de Microbiologia 38:25-30. 1996.

BEN-AMOR, K., BREEUWER, P., VERBAARSCHOT, P., ROMBOUTD, F.M., AKKERMANS, A.D.L., DE VOS, W.M. \& ABEE, T. Multiparametric flow cytometry and cell sorting for the assessment of viable, injured, and dead Bifidobacterium cells during bile salt stress. Applied and Environmental Microbiology 68:5209-5216. 2002.

BERNANDER, R., STOKKE, T. \& BOYE, E. Flow cytometry of 
bacterial cells: comparison between different flow cytometers and different DNA stains. Cytometry 31:29-36. 1998.

BREEUWER, P., DROCOURT, J.L., ROMBOUTS, F.M. \& ABEE, T. A novel method for continuous determination of the intracellular $\mathrm{pH}$ in bacteria with the internally conjugated fluorescent probe 5 (and 6-)-carboxyfluorescein succinimidyl ester. Applied and Environmental Microbiology 62:178-183. 1996.

BUNTHOF, C.J., VAN DEN BRAAK, S., BREEUWER P., ROMBOUTS F.M. \& ABEE T. Rapid fluorescence assessment of the viability of stressed Lactococcus latis. Applied and Environmental Microbiology 65:3681-3689. 1999.

BUNTHOF, C.J., BLOEMEN, P., BREEUWER P., ROMBOUTS F.M. \& ABEE T. Flow cytometric assessment of viability of lactic acid bacteria. Applied and Environmental Microbiology 67:23262335. 2001.

CHITARRA, L.G., BREEUWER P., VAN DEN BULK, R.W.\& ABEE, T. Rapid fluorescence assessment of intracellular $\mathrm{pH}$ as a viability indicator of Clavibacter michiganensis subsp. michiganensis. Journal of Applied Microbiology 88:809-816. 2000.

CHRZANOWSKI, T.H., CROTTY, R.D., HUBBARD, J.G. \& WELCH, R.P. Applicability of the fluorescein method of detecting active bacteria in freshwater. Microbial Ecology 10:179-185. 1984.

CRISSMAN, H.A., ORLICKY, D.J. \& KISSANE, R.J. Fluorescent DNA probes for flow cytometry. Considerations and prospects. Journal Histochemistry Cytochemistry 27:1654-1655. 1979.

DAVIS, M.J., GILLASPIE, A.G.JR., VIDAVER, A.K. \& HARRIS, R.W. Clavibacter: a new genus containing some phytopathogenic coryneform bacteria, including Clavibacter xyli subsp. xyli sp. nov., subsp. nov. \& Clavibacter xyli subsp. cynodontis subsp. nov., pathogens that cause ratoon stunting disease of sugarcane and bermudagrass stunting disease. International Journal of Systematic Bacteriology 34:107-117. 1984.

DIAPER, J.P. \& EDWARDS, C. Flow cytometric detection of viable bacteria in compost. FEMS Microbiology Ecology 14:213220. 1994a.

DIAPER, J.P. \& EDWARDS, C. The use of fluorogenic esters to detect viable bacteria by flow cytometry. Journal of Applied Bacteriology 77:221-228. 1994b.

EDWARDS, C., DIAPER, J.P., PORTER, J. \& PICKUP, R. Applications of flow cytometry in bacterial ecology. In: Lloyd, D. (Ed.). Flow cytometry in microbiology. London. Springer. 1993. pp.121-129.

ENDO, H., NAKAYAMA, J., HAYASHI, T. \& WATANABE, E. Application of flow cytometry for rapid determination of cell number of viable bacteria. Fisheries Science 63:1024-1029. 1997.

GREGORI, G., CITTERIO, S., GHIANI, A., LABRA, M., SGORBATI, S., BROWN, S. \& DENIS, M. Resolution of viable and membrane-compromised bacteria in freshwater and marine waters based on analytical flow cytometry and nucleic acid double staining. Applied and Environmental Microbiology 67:4662-4670. 2001.

GUNASEKERA, T.S., VEAL, D.A. \& ATTFIELD, P.V. Potential for broad applications of flow cytometry and fluorescence techniques in microbiological and somatic cell analysis of milk. International Journal of Food Microbiology 85:269-279. 2003.
HAUGLAND, R.P. Handbook of fluorescent probes and research chemicals, $6^{\text {th }}$ ed. Eugene OR, USA. Molecular Probes, Inc. 1996. p. 679.

HEWITT, C.J. \& NEBE-VON-CARON, G. An industrial application of multiparameter flow cytometry: assessment of cell physiological state and its application to the study of microbial fermentations. Cytometry 44:179-187. 2001.

HUDSON, B., UPHOLT, W.B., DIVINNY, J. \& VINOGRAD, J. The use of an ethidium bromide analogue in the dye-buoyant density procedure for the isolation of closed circular DNA: the variation of the superhelix density of mitocondrial DNA. Proceedings National Academy Sciences ot the USA 62:813-820. 1969.

KANESHIRO, E.S., WYDER, M.A., WU, Y.P. \& CUSHION, M.T. Reliability of calcein acetoxy methyl ester and ethidium homodimer or propidium iodide for viability assessment of microbes. Journal of Microbiological Methods 17:1-16. 1993.

KAPRELYANTES, A.S. \& KELL, D.B. The use of 5-cyano-2,3ditolyl tetrazolium chloride and flow cytometry for the visualization of respiratory activity in individual cells of Micrococcus luteus. Journal of Microbiological Methods 17:115-122. 1993a.

KAPRELYANTES, A.S. \& KELL, D.B. Dormancy in stationary phase cultures of Micrococcus luteus: flow cytometric analysis of starvation and resuscitation. Applied and Environmental Microbiology 59:3187-3196. 1993b.

LANGSRUD, S. \& SUNDHEIM, G. Flow cytometry for rapid assessment of viability after exposure to a quartenary ammonium compound. Journal of Applied Bacteriology 81:411-418. 1996.

LOPES-AMOROS, R., CASTEL, S., COMAS-RIU, J. \& VIVESREGO, J. Assessment of E. coli and Salmonella viability and starvation by confocal laser microscopy and flow cytometry using rhodamine $123, \mathrm{DiBAC}_{4}(3)$, propidium iodide, and CTC. Cytometry 298:298-305. 1997.

LUDOVICO, P., SANSONETTY, F. \& CORTE-REAL, M. Assessment of mitochondrial membrane potential in yeast cell populations by flow cytometry. Microbiology 147:3335-3343. 2001.

LUPPENS, S.B., BARBARAS, B., BREEUWER, P., ROMBOUTS, F.M. \& ABEE, T. Selection of fluorescent probes for flow cytometric viability assessment of Listeria monocytogenes exposed to membrane-active and oxidizing disinfectants. Journal of Food Protection 66:1393-1401. 2003.

MAGARIÑOS, B., ROMALDE, J.L., CID, A. \& TORANZO, A.E. Viability of starved Pasteurella piscicida in seawater monitored by flow cytometry and the effect of antibiotics on its resuscitation. Letters in Applied Microbiology 24:122-126. 1997.

MASON, D.J., LOPES-AMOROS, R., ALLMAN, R., STARK, J.M. \& LLOYD, D. The ability of membrane potencial dyes and calcafluor white to distinguish between viable and non-viable bacteria. Journal of Applied Bacteriology 78:309-315. 1995.

MILES, A.A. \& MISRA, S.S. The estimation of the bacterial power of the blood. The Journal of Hygiene 38:732-749. 1933.

NIELSEN, J.L., AQUINO DE MURO, M. \& NIELSEN, P.H. Evaluation of the redox dye 5-cyano-2,3-tolyl-tetrazolium chloride for activity studies by simultaneous use of microautoradiography and fluorescence in situ hybridization. Applied and Environmental Microbiology 69:641-643. 2003.

PLIHON, F., TAILLANDIER, P. \& STREHAIANO, P. A direct 
and simple method for rapid counting viable chains of Leuconostoc in batch cultures. Biotechnology Techniques 9:451-456. 1995.

PORTER, J., PICKUP R. \& EDWARDS, C. Evaluation of flow cytometric methods for the detection and viability assessment of bacteria from soil. Soil Biology and Biochemistry 29:91-100. 1997.

SGORBATI, S., BARBESTI, S., CITTERIO, S., BESBETTI, G. \& DE VECCHI R. Characterization of number, DNA content, viability and cell size of bacteria from natural environments using DAPI/PI dual staining and flow cytometry. Minerva Biotecnologica 8:9-15. 1996.

TAYLOR, I.W. \& MILTHORPE, B.K. An evaluation of DNA fluorochromes, staining techniques, and analysis for flow cytometry. I.Unperturbed cell population. Journal of Histochemistry and
Cytochemistry 28:1224-1232. 1980.

WIDHOLM, J.M. The use of fluorescein diacetate and phenosafranine for determining viability of cultured plant cells. Stain Technology 47:189-194. 1972.

WILLIAMS. S.C., HONG, Y., DANAVALL, D.C.A., HOWARDJONES, M.H., GIBSON, D., FRISCHER, M.E. \& VERITY, P.G. Distinguish between living and nonliving bacteria: evaluation of the vital stain propidium iodide and its combined use with molecular probes in aquatic samples. Journal of Microbiological Methods 32:225-236. 1998.

YAMAGUCHI, N., SASADA, M., YAMANAKA, M. \& NASU, M. Rapid detection of respiring Escherichia coli O157:H7 in apple juice, milk, and ground beef by flow cytometry. Cytometry 54A:27-35. 2003. 